This document is published in:

Ceramics International, Vol. 40, Issue 2 (March 2014), pp. 3063-3070 DOI: http://dx.doi.org/10.1016/i.ceramint.2013.09.140

(C) 2013 Elsevier Ltd and Techna Group S.r.I. 


\title{
Degradation of alumina refractory bricks by sintering Mn low-alloy steels
}

\author{
Mónica Campos ${ }^{\mathrm{a}, *}$, Jose Antonio Sicre-Artalejo ${ }^{\mathrm{a}}$, Jose Manuel Torralba ${ }^{\mathrm{a}, \mathrm{b}}$, Hannes Zbiral ${ }^{\mathrm{c}}$, \\ Herbert Danninger ${ }^{c}$, P. Pena ${ }^{\mathrm{d}}$ \\ ${ }^{a}$ Department of Materials Science and Engineering, IAAB, Carlos III University, 28911 Leganés, Spain \\ ${ }^{\mathrm{b}}$ IMDEA Materials Institute, C/ Eric Kandel, 2 Tecnogetafe, 28906 Getafe, Spain \\ ${ }^{\mathrm{c}}$ Technische Universität Wien, Institut für Chemische Technologien und Analytik, A-1060 Vienna, Austria \\ dinstituto de Ceramica y Vidrio, CSIC, Campus de Cantoblanco, 28049 Madrid, Spain
}

\begin{abstract}
The economic importance of the corrosion and wear of refractory materials is indisputable because these processes determine the viability of any hightemperature liner used in metallurgical processes. The degradation mechanism of lining materials (refractory bricks) in contact with corrosive gases can be studied by examining the penetration rate or the chemical corrosion that results from the circulation of the atmosphere over the refractory material (by diffusional and convective transport). During the sintering of steel containing Mn, the high vapour pressure of Mn enables its sublimation during thermal cycling; therefore, $\mathrm{Mn}$ is incorporated into the sintering atmosphere. Although the diffusion of $\mathrm{Mn}$ in steel samples is beneficial, the presence of Mn in a sintering atmosphere can modify the composition of refractory components. As a result of atmosphere-refractory interactions, a new phase is formed. In this study, the changes in refractory materials as a function of exposure time to atmospheres containing $\operatorname{Mn}_{(\mathrm{g})}$ at the most common sintering temperature, $1120{ }^{\circ} \mathrm{C}$, were investigated. The microstructural changes in the refractory materials and the consequences of the presence of $\mathrm{Mn}_{(\mathrm{g})} \mathrm{were}$ analysed using optical microscopy, electron microscopy with X-ray (EDS) microanalysis, X-ray diffraction, and X-ray fluorescence (XRF).
\end{abstract}

Keywords: B. Microstructure; C. Corrosion; C. Diffusion; D. Spinels; E. Refractories

\section{Introduction}

Multiple processes contribute to the corrosion of refractory materials, but these processes are always based on the physicochemical properties of the corrosive agent and on the intrinsic properties of the refractory materials, such as interconnected porosity and the presence of multiple phases. A highly interconnected porosity facilitates access to external agents and increases the reactive surface area, which favours material interactions and corrosion. In addition, the majority of refractory materials are multi-phase materials, which facilitates preferential attack [1]. Independent of the activation mechanism, products that alter the behaviour of refractory materials are generated, which usually accelerates their decay and reduces their service life.

\footnotetext{
*Corresponding author. Tel.: +34 916249916; fax: +34 916249430

E-mail addresses: campos@ing.uc3m.es, monica.campos@uc3m.es (M. Campos).
}

Because the metallurgical processes for which ceramics are utilised as lining materials reach very high temperatures, the associated corrosion phenomena are very complex.

Phase diagrams are useful tools for studying moderately complex corrosion processes in refractory materials. These diagrams enable the determination of the predominant attack mechanisms and their consequences during the corrosion process. However, there are other relevant phenomena that occur simultaneously with compositional modification that are not included in these diagrams. For instance, the volume changes associated with phase transitions can increase or reduce the surface exposed to the attack of an external agent and can also introduce residual stresses.

In the case of furnaces used for the sintering of low-alloy steels, the refractory components used as lining materials are not exposed to molten slag or liquid metals, their deterioration is associated with the composition of the sintering atmosphere. Reducing atmospheres composed of $90 \% \mathrm{vN}_{2}-10 \% \mathrm{vH}_{2}$ mixtures are most frequently used for sintering low-alloy 
steels with $\mathrm{Mn}$. This work discusses the effects of $\mathrm{Mn}_{(\mathrm{g})}$ on the chemical corrosion mechanism of refractory brick. The renewed interest in $\mathrm{Mn}$ as an alloy element in sintered steels is due to its low cost compared to the cost of, for example, $\mathrm{Ni}$ or Mo and because of the excellent properties that can be attained either in the as-sintered state or after heat treatment, irrespective of its high oxygen affinity, which has previously limited its use in powder metallurgy [2-6].

There are multiple metallurgical advantages of the incorporation of $\mathrm{Mn}$ into an alloyed steel in addition to its cost, as reported in one of the first published works on this alloy element [7]. Because of the high vapour pressure of $\mathrm{Mn}$, the element sublimes at typical sintering temperatures, $1120^{\circ} \mathrm{C}$, which results in the so-called "Mn self-cleaning effect" [8,9]. The first studies on the evaporation and condensation of manganese during sintering revealed that the sublimation and condensation of manganese vapours begins to effectively occur at $700{ }^{\circ} \mathrm{C}$ in either mixed $\mathrm{N}_{2}-\mathrm{H}_{2}$ atmospheres or in pure $\mathrm{H}_{2}$ and that these phenomena are closely related to the particle size of this element $[10,11]$. During this process, the reducing agents present in the sintering atmosphere are modified, and two possible behaviours are postulated according to the reactions described by Eqs. (1) and (2). Salak proposed in [10] that part of the Mn vapour can be oxidised by atmospheric oxygen, thereby removing oxygen from the atmosphere and reducing its partial pressure, which contributes to a reduction in the dew point and facilitates the sintering of low-alloy steel. As proposed by Cias [12], at temperatures above $920^{\circ} \mathrm{C}$, sublimated $\mathrm{Mn}$ can react with water vapour in the sintering atmosphere, producing $\mathrm{H}_{2}$, according to the reaction described by Eq. (2), which increases the reducing character of the atmosphere, as described by Eq. (3). Therefore, $\mathrm{Mn}_{(\mathrm{g})}$ can enhance the reduction of iron oxides.

$$
\begin{aligned}
& \mathrm{Mn}(\mathrm{g})+\mathrm{O}_{2} \leftrightarrow 2 \mathrm{MnO}[8] \\
& \mathrm{Mn}(\mathrm{g})+\mathrm{H}_{2} \mathrm{O} \leftrightarrow \mathrm{MnO}+\mathrm{H}_{2}[12] \\
& \mathrm{MO}+\mathrm{H}_{2} \leftrightarrow \mathrm{M}+\mathrm{H}_{2} \mathrm{O}
\end{aligned}
$$

If the Ellingham-Richardson diagram is considered, dew points close to $-55{ }^{\circ} \mathrm{C}$ for a sintering temperature of $1120{ }^{\circ} \mathrm{C}$ would be required to achieve the reduction of $\mathrm{MnO}$. However, due to the reactions described by Eqs. (4), (5), and (7), sintering can be effective at a dew point of $-30{ }^{\circ} \mathrm{C}$.

$$
\begin{aligned}
& \mathrm{MO}+\mathrm{C} \leftrightarrow \mathrm{M}+\mathrm{CO} \\
& \mathrm{C}+\mathrm{CO}_{2} \leftrightarrow 2 \mathrm{CO} \\
& \mathrm{C}+\mathrm{H}_{2} \mathrm{O} \leftrightarrow \mathrm{H}_{2}+\mathrm{CO}\left(T>930{ }^{\circ} \mathrm{C}\right) \\
& \mathrm{MO}+\mathrm{CO} \leftrightarrow \mathrm{M}+\mathrm{CO}_{2}
\end{aligned}
$$

Additionally, the incorporation of carbon (as graphite) into steel adds another reducing agent that interacts with the metallic powder (Eq. (5)) and with the sintering atmosphere (Eqs. (4)-(6)). Due to all of these effects, sintering at conventional temperatures $\left(1120^{\circ} \mathrm{C}\right)$ can be performed in atmospheres with standard dew points and without the need of elevated purity, which favours process continuity and consequently its practice in industry. However, it should be noted that a considerable proportion of all of the oxygen present in the system is introduced through the base powder, e.g., Fe. In the case of mixed powders, during heating, oxygen is transferred from iron to the $\mathrm{Mn}$ (carrier) powder, i.e., what occurs is a manganothermic reduction of the iron oxides ("internal getter effect"), resulting in the formation of oxides that are difficult to reduce, requiring high temperatures [13].

The complexity of sintering atmospheres and the changes in composition that occur depending on the stage of thermal cycling make studying the effects of the presence of $\mathrm{Mn}_{(\mathrm{g})}$ formed during sintering on furnace refractories especially interesting. Despite the high oxidation activity of manganese, some of it could be present in the form of finely dispersed $\mathrm{MnO}$ particles [14].

Irrespective of the state of the corrosive agent, for refractory materials used in metallurgical furnaces, three corrosion mechanisms have been identified [15-17]. Depending on where the attack occurs, the mechanisms are (1) surface dissolution, (2) grain boundary penetration, and/or (3) penetration through interconnected porosity. These mechanisms can occur either individually or in combination. In the present study, the type of attack produced by an external agent $\left(\mathrm{Mn}_{\mathrm{g}}\right)$ and the reaction products formed on a porous alumina refractory used on muffles for band furnaces in the powder metallurgy industry was investigated.

\section{Experimental process}

To study corrosion in refractory materials, Cremer Thermoprozessanlagen $\mathrm{GmbH}$ provided porous alumina bricks that are routinely used in industrial sintering furnaces. The as-received refractory samples were characterised using the guidelines proposed in [17]. Approximately $100 \mathrm{~g}$ of the refractory brick was ground to a particle size below $70 \mu \mathrm{m}$. The phases present in the initial samples were determined by X-ray powder diffractometry. The XRD patterns were obtained using an automated Philips X'Pert diffractometer with $\mathrm{Cu} \mathrm{K}_{\alpha}$ radiation $(\lambda=1.5418 \AA)$. The patterns were recorded from $20^{\circ}$ to $110^{\circ}$ $2 \theta$ in steps of $0.02^{\circ}$.

Imaging and semi-quantitative analysis were performed using an SEM (Philips XL-30) equipped with an energy dispersive spectrometry (EDS) detector system from EDAX DX-4. The composition was determined using a semiquantitative routine.

The following experimental process was designed to monitor and evaluate the chemical corrosion of the refractory material. A powder mixture of Fe:Mn $(50 \mathrm{~g})$ was deposited in a dense alumina tray (99.97\% purity), which was covered with the refractory sample to be studied (as displays Fig. 1). Different samples (bricks) were subjected to consecutive sintering cycles, as illustrated in Fig. 2, from 1 sintering cycle to 6 consecutive cycles. Individual sintering cycles were designed to have a dwell of three hours at the maximum temperature $\left(1120{ }^{\circ} \mathrm{C}\right)$ in a $90 \%$ $\mathrm{vN}_{2}-10 \% \mathrm{vH}_{2}$ atmosphere (routinely used when sintering this type of steel) and heating and cooling rates of $5{ }^{\circ} \mathrm{C} / \mathrm{min}$. During cooling, a $\mathrm{N}_{2}$ atmosphere was used. In all cases, the dew point was $25^{\circ} \mathrm{C}$. The time spent at the maximum temperature was 


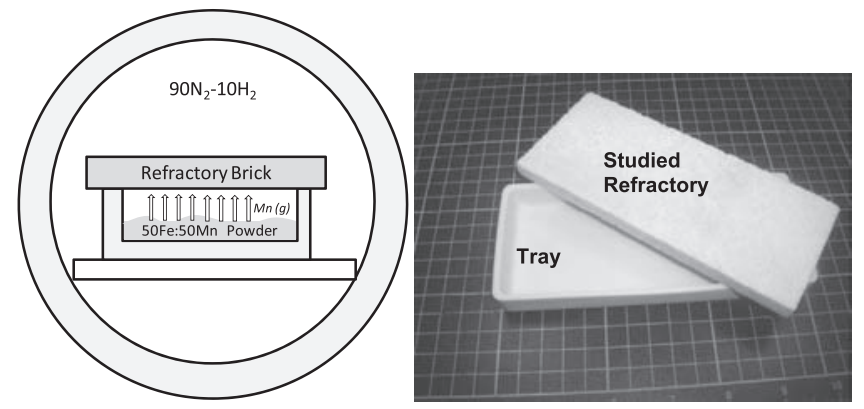

Fig. 1. Schematic of the alumina refractory brick (samples) and the Mn (external agent) in the tube furnace used for the exposure of the refractory material to sintering conditions. Specimen dimensions: $16 \times 6 \times 1 \mathrm{~cm}^{3}$.

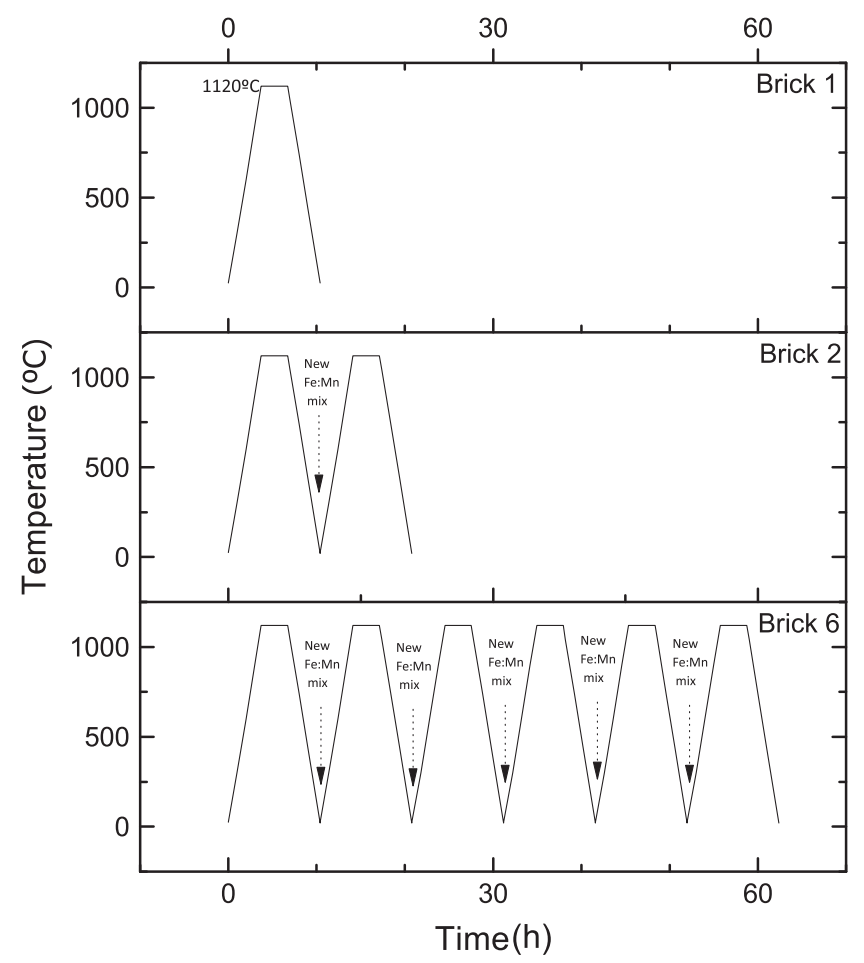

Fig. 2. Thermal cycles designed for exposing the refractory material to sintering Mn steels. Fe:Mn mixture was renewed after three hours at the sintering temperature, $1120^{\circ} \mathrm{C}$.

considered the exposure time to the sintering environment; therefore, bricks were measured and characterised after 3, 6, 9, 12,15 , and $18 \mathrm{~h}$ of exposure at $1120^{\circ} \mathrm{C}$.

To ensure that the same amount of elemental Mn powder was available for sublimation, the mixture was renewed after each sintering cycle, maintaining the same environment for each experiment (Fig. 2). Although in industrially manufactured PM parts the concentration of $\mathrm{Mn}$ is never above $2 \%$ for this type of low-alloy steel, the experiment was performed using mixtures with a higher proportion of $\mathrm{Mn}$ to accelerate the process, which enabled the corrosion mechanism to be observed.

To prepare a homogeneous $\mathrm{Mn} / \mathrm{Fe}$ powder mixture, a wateratomised $\mathrm{Fe}$ powder (ASC100.29, Höganäs $\mathrm{AB}$ ) and an electrolytic Mn powder with a particle size distribution of 45 to $125 \mu \mathrm{m}$ (provided by HidroNitro SA) were placed in a 50:50 ratio in a turbula mixer (WAB T2F) for $30 \mathrm{~min}$ in air at $49 \min ^{-1}$.

The degree of corrosion of the ceramic brick was studied by visual observation, by microstructural evolution, and by the weight changes in the refractory sample and in the Fe:Mn powder mixture, which were monitored using a precision balance $( \pm 0.0001 \mathrm{~g})$ at room temperature.

To identify the degradation process and mechanisms of refractory material wear, the apparent densities were measured by weighing each sample, with the volume determined by physical measurements. Sample porosity was defined using this density value and by considering the pore-free density of $\alpha-\mathrm{Al}_{2} \mathrm{O}_{3}$.

To prepare cross-sections of the exposed specimens, the samples were cut with a diamond saw, embedded in a lowviscosity resin (acrylic KM-U from Presi) because of the porosity, ground, polished with diamond suspensions, and etched with an aqueous solution of 10\% $\mathrm{HF}$ if it was necessary. Finally, to provide a conductive layer for SEM examination, either $\mathrm{Au}$ or $\mathrm{C}$ coatings were sputtered on the material surfaces.

In addition, the chemical composition of the sample surfaces exposed to the corrosive agent was determined by X-ray diffraction (XRD) and by X-ray fluorescence spectroscopy (XRF) using a WDS-XRF X'Unique II model from Philips with $\mathrm{Rh} \mathrm{K} \alpha$ radiation. To establish the composition with this technique, a surface area of $20 \times 20 \mathrm{~mm}$ was scanned, reaching a maximum depth for analysis of $250 \mu \mathrm{m}$. It should be considered, however, that the majority of the signalsapproximately $90 \%$-were obtained from the near-surface area to a depth of approx. $10 \mu \mathrm{m}$.

\section{Results and analysis}

\subsection{Characterisation of the initial refractory material.}

The XRF analysis (Fig. 3) confirmed the elemental composition of the refractory material, and according to the X-ray diffraction measurement, the sample was exclusively composed of $\alpha$-alumina (Fig. 3, right). This type of refractory material is ideal for the proposed degradation study because of its chemical simplicity and its purity. Therefore, the determination of the new phases formed during the sintering process should be more precise.

Fig. 4 shows two SEM micrographs of the material. Two distinctive characteristics are observed: first, the porous material is partially composed of hollow spheres with a wide size distribution, and second, there is a high level of porosity between the spheres. These two factors are crucial to the study of the corrosion of the material because the high specific surface of the material will significantly favour the interaction between the Mn vapour and the refractory material.

The apparent density values corroborate the highly porous microstructure previously observed. The apparent density values were $1.42 \pm 0.05 \mathrm{~g} / \mathrm{cm}^{3}$, and the known density value 

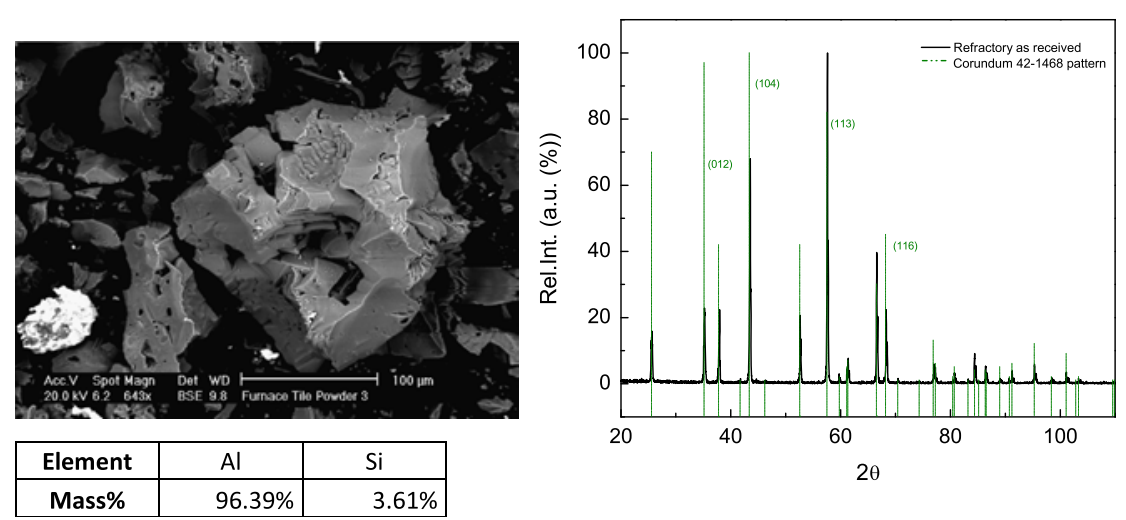

Fig. 3. Left: Details of the ground sample used for X-ray characterisation and results from the XRF analysis (oxygen is not included). Right: Diffractogram of the initial alumina sample; the planes corresponding to the most intense peaks are specified. Patterns: JCPDS 42-1468.
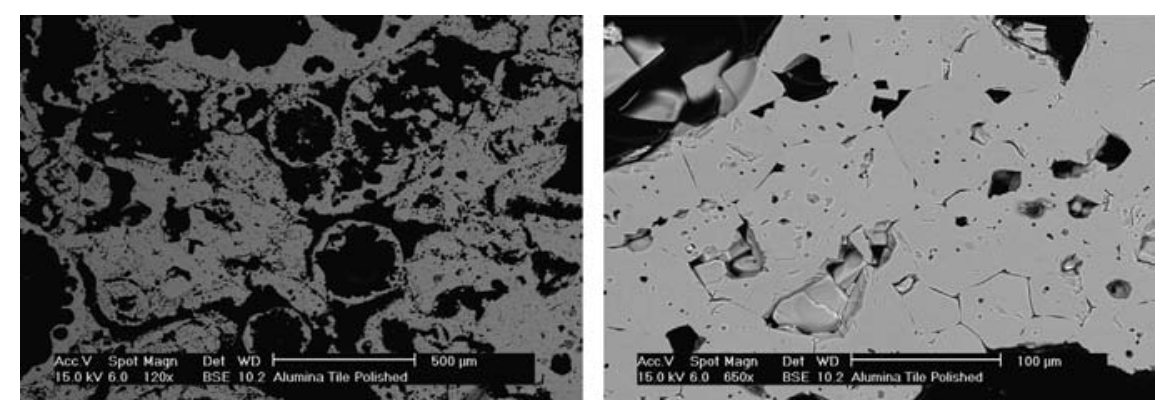

Fig. 4. SEM micrographs of the initial refractory sample, the ground sample and the sample exposed to a $10 \%$ HF solution for $1 \mathrm{~s}$. Left: Overview of the sample; different wall thicknesses and sizes are shown. Right: Microstructural details of the walls of the alumina sphere.

for alumina is $\rho_{\mathrm{th}} \approx 4.088 \mathrm{~g} / \mathrm{cm}^{3}$; therefore, the porosity of this material is approximately $65.2 \%$.

\subsection{Refractory degradation}

Unlike the furnaces used in conventional iron and steel industries, in sintering furnaces, the refractory materials are not in contact with a molten product that can generally give rise to corrosion processes, such as differential corrosion or, depending on the location of the contact zone, abrasive wear. The degradation of refractory materials in sintering furnaces results from the deposition of material onto the surface exposed to the sintering atmosphere. These deposits produce crusts that, if controlled and stable, can result in a very effective instrument for controlling the physicochemical corrosion of the installation, impeding further reactions. Crusts, however, can be counterproductive when the environment is subjected to abrupt temperature changes that can generate thermal stresses that bring about their detachment.

As described, to ensure the presence of $\mathrm{Mn}_{(\mathrm{g})}$ during the experiment, the $\mathrm{Fe}-\mathrm{Mn}$ powder mixture was renewed for every sintering cycle (Fig. 2). Therefore, the change in the weight of the refractory brick and the mixture of Fe:Mn powder was measured at the end of each thermal cycle, after three hours at maximum temperature.

In the case of the Fe:Mn powder mixture, an increase in weight was detected in each of the measurements. This increase was $\Delta m_{\text {powder-mix }}=0.82 \pm 0.34 \mathrm{~g}$, which is relatively small and attributed to the oxidation of the powder during the cooling process under $\mathrm{N}_{2}$. In this atmosphere, any reducing agents required to prevent the oxidation of the remaining iron and manganese powder were not present (i.e., $\mathrm{H}_{2}$ or $\mathrm{CO}$ ). However, the lack of reducing agents did not affect the degradation processes of the refractory sample, which began during heating and were maximised at the sintering temperature.

Fig. 5 shows the weight gain of the refractory brick sample as a function of exposure time, which linearly increases over the $18 \mathrm{~h}$ of exposure to the maximum temperature. Even with a low weight gain, optical microscopy revealed that the surface of the refractory samples was clearly altered as the total sintering time increased (Fig. 5).

\subsubsection{Effect of manganese on the microstructure: new phase formation}

The colour change (to a dark-green colour) on the surface of the refractory material as a result of the interaction between Mn vapour and alumina indicates the formation of a new phase as a crust on the surface [18]. To facilitate the determination of this new compound, the phase diagrams of the binary $\mathrm{MnO}$ $\mathrm{Al}_{2} \mathrm{O}_{3}$ system $[19,20]$ and the ternary $\mathrm{MnO}-\mathrm{Al}_{2} \mathrm{O}_{3}-\mathrm{SiO}_{2}$ system (shown in Fig. 6) [21,22] were considered.

Based on the X-ray diffraction data for the samples exposed to $\mathrm{Mn}$ vapours (Fig. 7), the formation of the spinel $\mathrm{MnO} \cdot \mathrm{Al}_{2} \mathrm{O}_{3}$, galaxite, was observed. Taking into account the phase diagram of Fig. 6, this spinel has a composition of $60 \mathrm{wt} \% \mathrm{Al}_{2} \mathrm{O}_{3}$ and $40 \mathrm{wt} \% \mathrm{MnO}$. Although the formation of galaxite reduces the working temperature of the alumina 


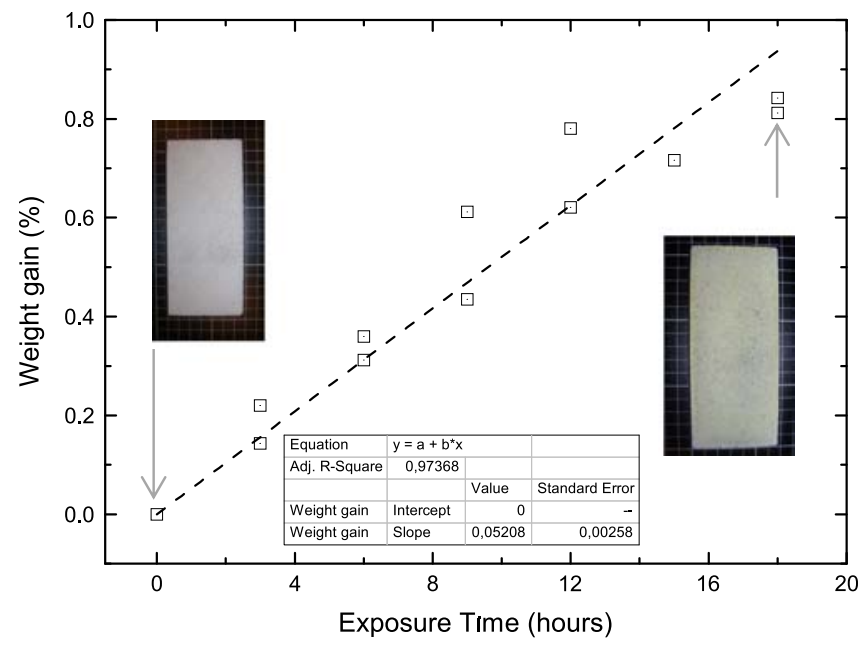

Fig. 5. Evolution of weight gain in the refractory sample as a function of exposure time to the external agent at $1120^{\circ} \mathrm{C}$.

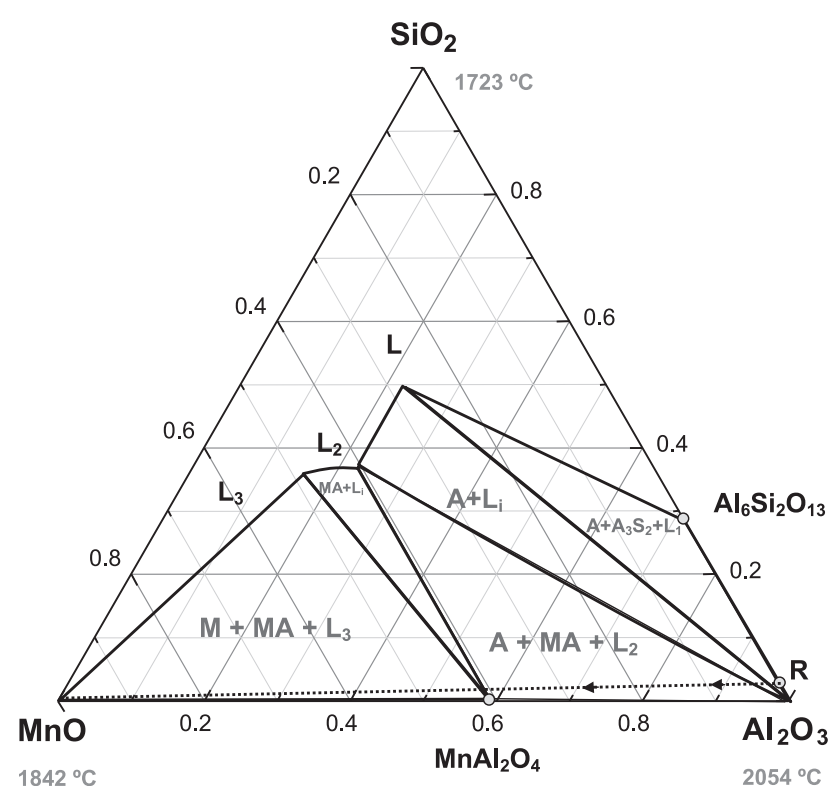

Fig. 6. Ternary system $\mathrm{MnO}-\mathrm{Al}_{2} \mathrm{O}_{3}-\mathrm{SiO}_{2}$ with outline of the corrosion process beginning from the initial composition of the studied refractory (R) to the formation of the spinel $\mathrm{MnAl}_{2} \mathrm{O}_{4}$. Labels: $\mathrm{M}$ (Manganosite, $\mathrm{MnO}$ ), MA (Galaxite, $\mathrm{MnO} . \mathrm{Al}_{2} \mathrm{O}_{3}$ ), A (Alumina, $\mathrm{Al}_{2} \mathrm{O}_{3}$ ), $\mathrm{A}_{3} \mathrm{~S}_{2}$ (Mullite, $3 \mathrm{Al}_{2} \mathrm{O}_{3} \cdot 2 \mathrm{SiO}_{2}$ ).

refractory, the invariant point temperature of galaxite-alumina is $1760 \pm 10{ }^{\circ} \mathrm{C}$, which is considerably higher than the experimental temperature of $1120^{\circ} \mathrm{C}$ and the normal sintering temperatures range, which remains between 1100 and $1250{ }^{\circ} \mathrm{C}$.

The experiment temperature was relatively close to the invariant point of $\mathrm{Al}_{2} \mathrm{O}_{3}-\mathrm{MnO} \cdot \mathrm{Al}_{2} \mathrm{O}_{3}-\mathrm{Mn}_{3} \mathrm{Al}_{2} \mathrm{Si}_{3} \mathrm{O}_{12}, \sim 1100{ }^{\circ} \mathrm{C}$, but as shown in Fig. 3, the small amount of silicon impurities detected by EDS did not permit the formation of liquid phases as a result of the corrosion process [23].

Fig. 6 indicates the composition of the refractory material (R) and the variation in the composition of this refractory as a
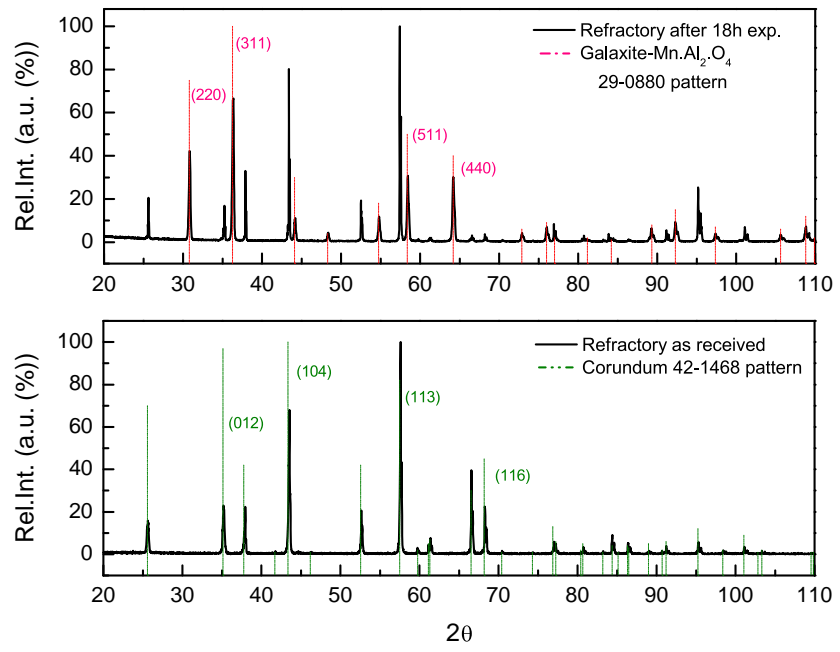

Fig. 7. Top: Diffractogram of the surface exposed to sintering for $18 \mathrm{~h}$. Bottom: diffractogram of the initial alumina sample. The planes corresponding to the most intense peaks are specified. Patterns: JCPDS 42-1468 \& 29-0880.

result of the corrosion process as a dotted line. Above this line, the expected phases of the corroded material are observed: $\alpha$ alumina, galaxite (spinel $\mathrm{MnO} \cdot \mathrm{Al}_{2} \mathrm{O}_{3}$ ) and a small amount of a vitreous phase (liquid phase at the temperature the corrosion experiment was performed).

Once the formation of the spinel $\mathrm{MnO} \cdot \mathrm{Al}_{2} \mathrm{O}_{3}$ was confirmed, the differences in the densities of the two compounds had to be considered (4.088 for alumina and $4.160 \mathrm{~g} \mathrm{~cm}^{-3}$ for the spinel). When considerable amounts of spinel are generated (for higher exposure times), the volume changes associated with the formation of the spinel can promote the formation of superficial microcracks, which deteriorate the surface of the refractory. These cracks should increase the material's susceptibility to the next corrosive agents, resulting in wear.

The surface of the brick of a galaxite crust can be considered a risk for crack initiation when the material will be used at high temperature. Considering the thermal coefficients reported in [24,25], 8.1 for dense alumina and $7.9 \mathrm{ppm} / \mathrm{K}$ for galaxite, the possibility of cracking induced by differences in expansion is minimal. However, it is important to consider that the specimen is porous alumina; therefore, a change in the coefficient can be expected, and the effect may not be negligible.

\subsubsection{Penetration into lining}

Due to the highly porous structure of the refractory specimens, the interaction with the atmosphere occurred over the entire cross-section of the bricks. A detailed study of the spinel microstructure deposited on the surface of the hollow alumina spheres reveals the polygonal growth of this crust (Fig. 8), in a manner similar to that previously reported in [26]. This growth was also detected in a microstructural study of the $\mathrm{MnO}-$ $\mathrm{Al}_{2} \mathrm{O}_{3}-\mathrm{SiO}_{2}$ system [22].

Because of the high porosity, galaxite not only formed a continuous layer on the surface of the alumina but has also significantly migrated into the material through the pore channels (Fig. 9). A detailed cross-section analysis revealed 

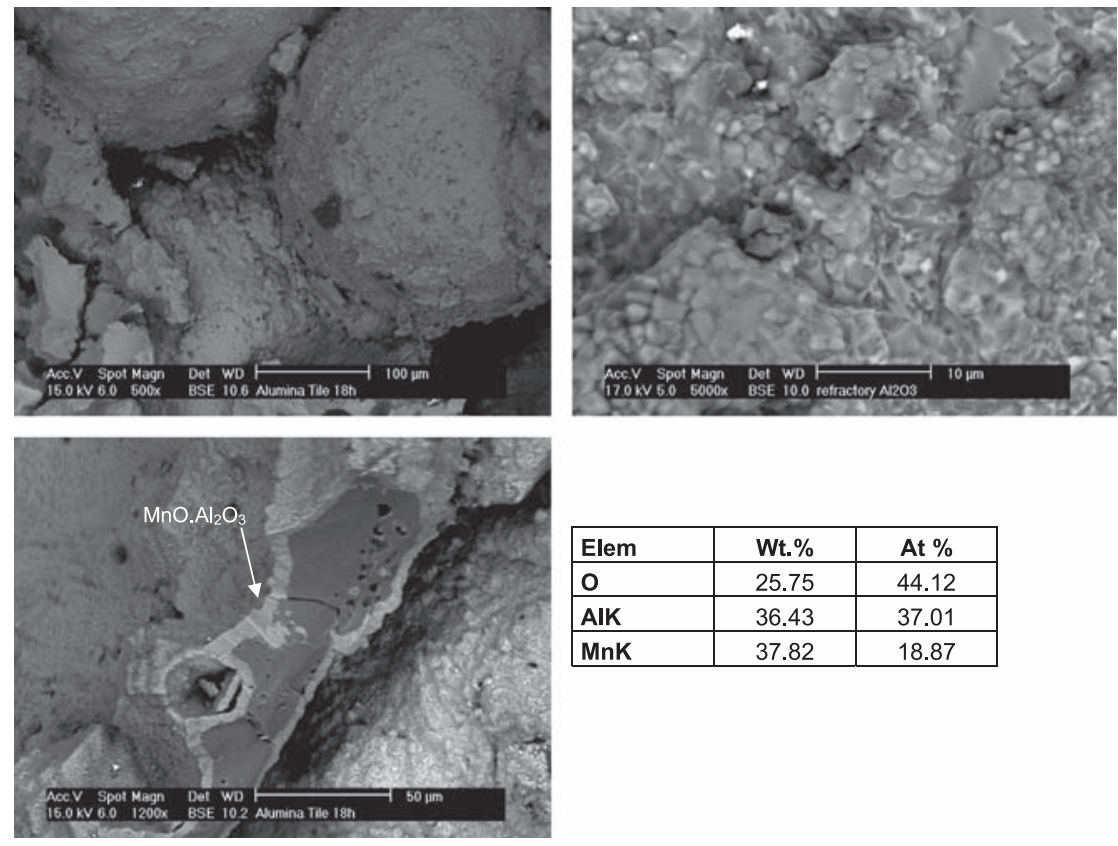

\begin{tabular}{|l|c|c|}
\hline Elem & Wt. $\%$ & At $\%$ \\
\hline O & 25.75 & 44.12 \\
\hline AlK & 36.43 & 37.01 \\
\hline MnK & 37.82 & 18.87 \\
\hline
\end{tabular}

Fig. 8. Left: Overhead image of crust formation of galaxite on the external surface of the refractory material after $18 \mathrm{~h}$ of exposure to the Mn-rich atmosphere. Right: Spinel microstructure, polygonal growth and EDS analysis results.
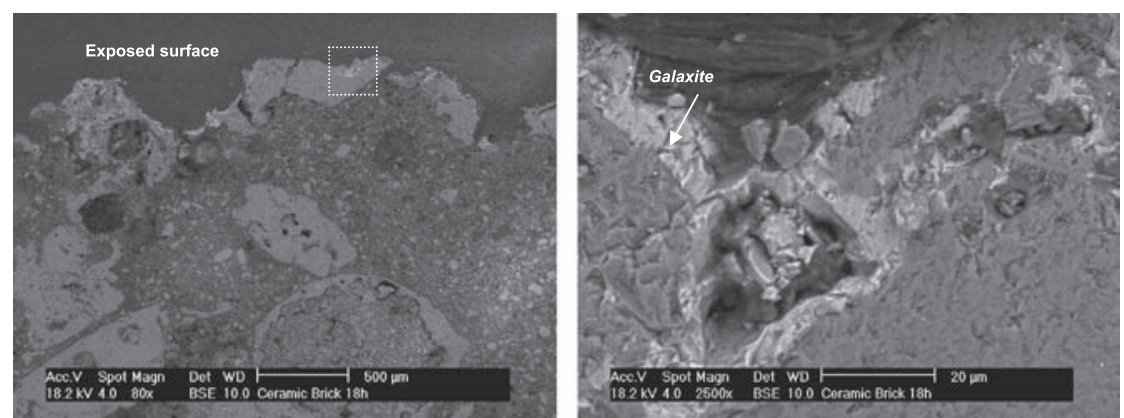

\begin{tabular}{|c|c|c|}
\hline Element & Wt. $\%$ & At $\%$ \\
\hline $\mathrm{O}$ & 12.06 & 24.7 \\
\hline AlK & 36.95 & 44.88 \\
\hline MnK & 50.98 & 30.41 \\
\hline
\end{tabular}

Fig. 9. Details regarding the formation of galaxite after $18 \mathrm{~h}$ exposure to the Mn-rich atmosphere. Left: General cross-sectional view. Right: Spinel crust marked in the square and EDS analysis results.

the penetration of $\mathrm{Mn}_{(\mathrm{g})}$, which resulted in galaxite formation over the entire pore surfaces, which occurred over a penetration distance equivalent to the width of the specimen, $10 \mathrm{~mm}$. There is no evidence of grain boundary Mn migration at this exposure interval. In this case, the corrosion mechanisms are dominated by the penetration of interconnected porosity, leading to phase modification at the surfaces.

To determine the amount of $\mathrm{Mn}$ that diffused into the surface of the alumina refractory, X-ray fluorescence studies were performed. The results of these studies are shown in Fig. 10. The amount of Mn in the sample increased with the exposure time and was fit with a third-order polynomial curve. Considering that the composition of the spinel is $40 \mathrm{wt} \%$ $\mathrm{Mn}: 60 \mathrm{wt} \% \mathrm{Al}_{2} \mathrm{O}_{3}$, the amount of Mn detected using XRF after $18 \mathrm{~h}$ of exposure indicates that the external agent $\left(\mathrm{Mn}_{\mathrm{g}}\right)$ probably has a penetration depth greater than the depth of the $\mathrm{XRF}$ analysis. Iron powders present in the mixture did not affect the composition of the refractory surface, proving that in the sintering of low-alloy steels with added Mn, iron powders do not contribute to changes in the composition of the sintering atmosphere.

\section{Conclusions}

Samples of porous $\mathrm{Al}_{2} \mathrm{O}_{3}$ (corundum) refractories typically used in sintering furnaces for low-alloy steels were exposed to sublimed manganese during sintering in a $90 \% \mathrm{vN}_{2}-10 \% \mathrm{vH}_{2}$ 


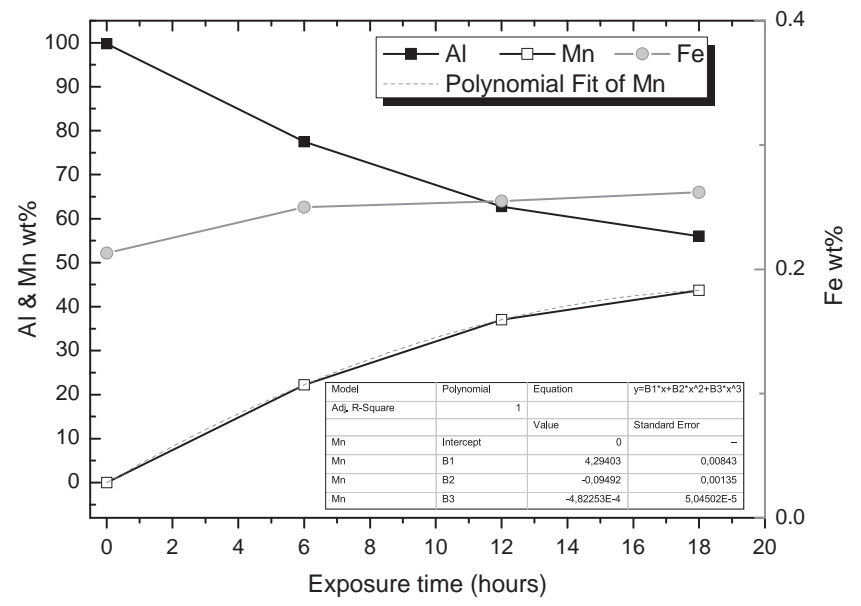

Fig. 10. Evolution of diffusion on the refractory surface as a function of exposure time determined by XRF.

atmosphere. Based on the microscopy, weight-change and $\mathrm{XRF}$ analyses, the following conclusions are drawn:

It was observed that the weight increase of the refractory brick, which was associated with the formation of the spinel material $\mathrm{MnO} \cdot \mathrm{Al}_{2} \mathrm{O}_{3}$, follows a linear evolution with respect to the time of exposure to the external agent, i.e., the process is not solid-state diffusion-controlled (which should result in a square root evolution with time).

Mn sublimation, which occurs close to $700-800{ }^{\circ} \mathrm{C}$, provides a corrosive agent, $\mathrm{Mn}_{\mathrm{g}}$, that interacts with refractory materials in furnaces. Specifically, in the case of alumina refractories, Mn diffuses into the brick and reacts with the refractory material to form the spinel galaxite $\left(\mathrm{MnO} \cdot \mathrm{Al}_{2} \mathrm{O}_{3}\right)$.

Because of the gaseous state of the external agent, and considering the significant porosity of the refractory material, the gas easily penetrates through the pore channels of the material. $\mathrm{XRF}$ analysis confirms the degree of $\mathrm{Mn}_{\mathrm{g}}$ penetration, detected over the entire scanned depth (at least $250 \mu \mathrm{m}$ ) after $18 \mathrm{~h}$.

The volume changes associated with the formation of the spinel accelerated the deterioration and wear of the refractory materials in the sintering furnace.

Although the conditions selected in this study, in particular, the amount of Mn that could react with the refractory, were definitely much more severe than those that might occur in industrial furnaces, the results are of great significance for manufacture of PM parts because the lower Mn concentration available at any moment is compensated for by a much longer exposure time, i.e., years instead of hours.

\section{Acknowledgements}

The authors would like to thank the Höganäs Chair in Powder Metallurgy for the scientific advice during the development of this work, Cremer Thermoprozessanlagen $\mathrm{GmbH}$ (Germany) for providing the refractory bricks and finally HidroNitro SA for providing the electrolytic Mn.

\section{References}

[1] A.H. de Aza, P. Pena, S. de Aza, M. Raigón, J. Gómez-Millán, C. Domínguez, Estudio post-mortem de un hormigón refractario colocado en la línea de escorias de una cuchara de acería, Boletín de la Sociedad Española de Cerámica y Vidrio 42 (3) (2003) 375-378.

[2] M. Campos, D. Sánchez, J.M. Torralba, Sintering behaviour improvement of a low $\mathrm{Cr}-\mathrm{Mo}$ prealloyed powder steel through Mn additions and other liquid phase promoters, Journal of Materials Processing Technology 143-144 (2003) 464-469.

[3] H. Danninger, C. Gierl, New alloying systems for ferrous powder metallurgy precision parts, Science of Sintering 40 (1) (2008) 33-46.

[4] J. Sicre-Artalejo, M. Campos, T. Marcu, J.M. Torralba, Modification of low alloyed steels by manganese additions, Materials Science Forum. 534-536 (2007) 697-700.

[5] M. Campos, L. Blanco, J. Sicre-Artalejo, J.M. Torralba, High performance low alloy steels: update, Revista de Metalurgia 44 (1) (2008) 5-12.

[6] E. Hryha, C. Gierl, N. Nyborg, H. Danninger, E. Dudrova, Surface composition of the steel powders pre-alloyed with manganese, Applied Surface Science 256 (12) (2010) 3946-3961.

[7] G. Zapf, G. Hoffman, K. Dalal, Effect of additional alloying elements on the properties of sintered Mn steels, Powder Metallurgy 18 (35) (1975) 214-236.

[8] A. Salak, Sintered manganese steels I: effect of structure of initial iron powders upon mechanical properties, Powder Metallurgy International 12 (1) (1980) 28-31.

[9] A. Salak, Sintered manganese steels. II: manganese evaporation during sintering, Powder Metallurgy International 12 (2) (1980) 72-75.

[10] A. Salak, Manganese vapor-protection of premixed manganese steels against oxidation during sintering, Powder Metallurgy International 18 (4) (1986) 266-270.

[11] G.S. Upadhyaya, Manganese In Powder Metallurgy Alloys, The Manganese Centre, Paris, 1986.

[12] A. Cias, S.C. Mitchell, K. Pilch, H. Cias, M. Sulowsky, A.S. Wronsky, Tensile properties of $\mathrm{Fe}-3 \mathrm{Mn}-0.6 / 0.7 \mathrm{C}$ steels sintered in semiclosed containers in dry hydrogen, nitrogen and mixtures thereof, Powder Metallurgy 3 (46) (2003) 165-170.

[13] H. Danninger, M. Jaliliziyaeian, C. Gierl, E. Hryha, S. Bengtsson Sintered steels prealloyed with manganese - chances and risks, in: Proceedings of the PM2010, European Powder Metallurgy Association, Shrewsbury, vol. 3, 2010.

[14] E. Hryha, E. Dudrova, L. Nyborg, Critical aspects of alloying of sintered steels with manganese, Metallurgical and Materials Transactions A 41 (11) (2010) 2880-2897.

[15] A.H. de Aza, Corrosión de materiales refractarios por escorias y vidrios fundidos, Boletín de la Sociedad Española de Cerámica y Vidrio 35 (2) (1996) 87-101.

[16] V. Petkov, P.T. Jones, E. Boydens, B. Blanpain, P. Wollants., Chemical corrosion mechanisms of magnesia-chromite and chrome-free refractory bricks by copper metal and anode slag, Journal of the European Ceramic Society. 27 (2007) 1433-2444.

[17] J. Stjernberg, J.C. Ion, M.-L. Antti, L.O. Nordin, B. Lindblom, M. Oden., Extended studies of degradation mechanisms in the refractory lining of a rotary kiln for iron ore pellet production, Journal of the European Ceramic Society. 32 (2012) 1519-1528.

[18] A.H. De Aza, F.J. Valle, P. Ortega, P. Pena, S. De Aza, Analytical characterization of a magnesia-graphite refractory, Journal of the American Ceramic Society 89 (5) (2006) 1704-1708.

[19] G. Eriksson, P. Wu, A.D. Pelton, Critical evaluation and optimization of the thermodynamic properties and phase diagrams of the $\mathrm{MgO}-\mathrm{Al}_{2} \mathrm{O}_{3}$ $\mathrm{MnO}-\mathrm{Al}_{2} \mathrm{O}_{3}, \mathrm{FeO}-\mathrm{Al}_{2} \mathrm{O}_{3}, \mathrm{Na}_{2} \mathrm{O}-\mathrm{Al}_{2} \mathrm{O}_{3}$ and $\mathrm{K}_{2} \mathrm{O}-\mathrm{Al}_{2} \mathrm{O}_{3}$ systems, CALPHAD 17 (2) (1993) 189-205.

[20] I. Jung, Y. Kang, S.A. Decterov, A.D. Pelton, Thermodynamic evaluation and optimization of the $\mathrm{MnO}-\mathrm{Al}_{2} \mathrm{O}_{3}$ and $\mathrm{MnO}-\mathrm{Al}_{2} \mathrm{O}_{3}-\mathrm{SiO}_{2}$ systems and applications to inclusion engineering, Metallurgical and Materials Transactions B 262 (35) (2004) 259-268. 
[21] United States Patent number: 5,314,549, High Strength and High Toughness Stainless Steel Sheet and Method for Producing thereof, May 1994.

[22] G. Roghani, E. Jak, P. Hayes, Phase-equilibrium studies in the $\mathrm{MnO}-\mathrm{Al}_{2} \mathrm{O}_{3}-$ $\mathrm{SiO}_{2}$ system, Metallurgical and Materials Transactions B 33 (6) (2002) 827-838.

[23] J. Zhou, S. Bahadur, Erosion characteristics of alumina ceramics at high temperatures, Wear 181 (1995) 178-188.

[24] R.E. Taylor, Thermal Expansion of Solids, ASM International, Materials Park, OH 44073-002 USA, 1998, p. 271.
[25] A. Petric, H. Lingw, Electrical conductivity and thermal expansion of spinels at elevated temperatures, Journal of the American Ceramic Society 90 (2007) 1515-1520.

[26] L.A. Diaz, R. Torrecillas, A.H. De Aza, P. Pena, S. De Aza, Alumina rich refractory concretes with added spinel, periclase and dolomite: a comparative study of their microstructural evolution with $\mathrm{T}$, Journal of the European Ceramic Society 25 (2005) 1499-1506. 